Indonesian Journal of Applied Linguistics, Vol. 4 No. I, July 20 I 4, pp.23-38

\title{
MULTIPLE INTELLIGENCES AS PREDICTORS OF READING COMPREHENSION AND VOCABULARY KNOWLEDGE
}

\author{
Abbas Ali Zarei \\ Associate professor, Imam Khomeini International University, Qazvin, Iran. \\ email: a.zarei@hum.ikiu.ac.ir \\ Nima Shokri Afshar \\ Islamic Azad University, Takestan \\ email: aazarei@yahoo.com
}

\begin{abstract}
The present study was conducted to investigate types of Multiple Intelligences as predictors of reading comprehension and vocabulary knowledge. To meet this objective, a 60-item TOEFL test and a 90-item multiple intelligences questionnaire were distributed among 240 male and female Iranians studying English at Qazali and Parsian Universities in Qazvin. Data were analyzed using a multiple regression procedure. The result of the data analysis indicated that musical, interpersonal, kinesthetic, and logical intelligences were predicators of reading comprehension. Moreover, musical, verbal, visual, kinesthetic and natural intelligences made significant contributions to predicting vocabulary knowledge.
\end{abstract}

Key words: Multiple intelligences, reading comprehension, vocabulary knowledge.

\section{KECERDASAN MAJEMUK UNTUK MEMPREDIKSI MEMBACA PEMAHAMAN DAN PENGETAHUAN KOSAKATA}

\begin{abstract}
Abstrak: Penelitian ini dilakukan untuk mengetahui tipe-tipe kecerdasan majemuk sebagai prediktor dari membaca pemahaman dan pengetahuan kosa kata. Untuk mencapai tujuan tersebut, sebuah tes TOEFL terdiri dari 60 pertanyaan dan kuesioner mengenai kecerdasan majemuk yang terdiri dari 90 pertanyaan disebarkan kepada 240 mahasiswa laki-laki dan perempuan Iran yang belajar Bahasa Inggris di Universitas Qazali dan Parsian di Qazvin. Data dianalisis menggunakan multi regresi. Hasil dari data analisis menunjukkan bahwa kecerdasan musik, interpersonal, kinestetik, dan matematis logis merupakan prediktor membaca pemahaman. Lebih lanjut, kecerdasan musikal, verbal, visual, kinestetik, dan naturalis memberikan kontribusi signifikan dalam memprediksi pengetahuan kosa kata.
\end{abstract}

Katakunci: Kecerdasan majemuk, membaca pemahaman, pengetahuan kosa kata.

Until early 1980s, intelligence was regarded as a unitary trait. In 1983, the idea of general intelligence was replaced with multiple intelligences. Gardner (1983) revolutionized the view of intelligence. He argues that MI Theory pluralizes the traditional concept. Gardner claims that human beings possess not just a single intelligence, but a set of relatively autonomous intelligences. These different and autonomous intelligence capacities result in many different ways of knowing, understanding, and learning about the world. Gardner (1999) defines intelligence 
as a "biopsychological potential to process information that can be activated in a cultural setting to solve problems or create products that are of value in a culture" (pp. 33-34).

According to Gardner (1999), intelligence is more than IQ because the IQ test only measures logical and verbal intelligences. He states that besides the above two types of intelligence, individuals have seven more intelligences including visual, kinesthetic, musical, interpersonal, intrapersonal, naturalist, and existential intelligences. The present study is concerned with types of MI as predictors of reading comprehension and vocabulary knowledge. Examination of our current understanding of the relationships among MI, reading comprehension and vocabulary knowledge indicates the need for a richer understanding of this relationship. The objective of this study, therefore, is to explore to what extent or in what combination, intelligences are predictors of reading comprehension and vocabulary knowledge. More specifically, the purpose of the present study is to answer the following research questions: (1) Which of the multiple intelligence types is a better predictor of reading comprehension? And, (2) Which of the multiple intelligence types is a better predictor of vocabulary knowledge?

Green andTanner (2005) hold that each person has an individual intelligence profile, consisting of different capacities that are related to all the nine intelligences. These intelligences constitute how individuals process information. In addition, Multiple Intelligence theory supports the idea of existence of a number of intelligences that result in a unique cognitive profile for each person.

Gardner (1999) differentiates between intelligence and domain. $\mathrm{He}$ defines intelligence as a person's biopsychological potential by virtue of their species membership, but domain is viewed as a socially constructed human endeavor. As such, several intelligences can be applied in the same domain, and the same intelligences in many domains.

Razmjoo (2008) refers to analytical, introspective and interactive domains as the three domains of multiple intelligences which can serve as an organizer for exploring and understanding the relationships among the intelligences and how multiple intelligences work with one another. McKenzie (2002) states that each domain has its own sub-branches. The analytic domain includes the musical, logical and naturalist intelligences; these three intelligences promote the processes of analyzing and incorporating data into existing schema. The interactive domain contains the interpersonal, kinesthetic and linguistic intelligences; these three intelligences encourage interaction to achieve understanding. The introspective domain includes existential, visual and intrapersonal intelligences; these three intelligences require a looking inward by the learner, an emotive connection to his/her own experiences to make sense of new learning. The analytical, interactive and introspective intelligences are by their nature heuristic, social and affective processes, respectively.

Gardner (1983) defines linguistic intelligence as the ability to use language as a means to understand the order and the meaning of words. Logical/mathematical intelligence requires the ability to calculate and to understand the various patterns or reasons in a systematic and logical manner. It is associated with mathematical and scientific thinking. Visual/spatial intelligence involves the ability to know, think and create mental images, shapes, patterns, and designs in order to solve problems. Musical intelligence includes the 
ability to make and recognize music, sing and to understand or use rhythm. Auditory functions and recognition of tonal and rhythmic patterns are required for a person to develop this intelligence. Music smart includes thinking in sounds and patterns, performing music and leading in songs. Musicians, singers, voice coaches, and composers exhibit musical intelligence (Armstrong, 1994). Bodily/kinesthetic intelligence is the ability to use one's body skillfully to solve problems. It challenges and contradicts the belief that mental and physical activities are unrelated. Interpersonal intelligence involves individuals using their social skills to understand and notice people's motivations, temperaments and goals. It involves cooperating and communicating with others. Typical roles are therapists, leaders, educators, teachers, doctors and coaches (Gardner, 1993). Intrapersonal intelligence is the ability to distinguish, reflect, analyze and identify various personal thoughts and feelings and to use them to understand and plan one's own behaviour. Self-awareness, personal objectivity, and one's relationship to others and the world are important in this intelligence. Naturalist intelligence displays empathy, recognition, and understanding for living and natural things. It allows individuals to distinguish, classify and use features of the natural world around them. Typical roles are farmers, geologists and gardeners who can name and describe the features of environment (Gardner, 1999). Finally, Gardner associates existential intelligence with people who are able to comprehend fundamental questions and issues of existence. They are most comfortable and productive when they are discussing or writing about experiences.

\section{MI theory and language teaching}

As Christison (1999) proposes, the theory of multiple intelligences should be introduced to language educators in order to demonstrate how to use multiple intelligences in lesson planning, language learning tasks, and assessment. She claims that it is encouraging for language educators to develop all intelligences to a reasonably high level.

According to Armstrong (1995), the first step in using multiple intelligence theory is to determine the educator's own multiple intelligence profile. $\mathrm{He}$ adds that as educators learn more about their own profile, they will become more confident in the choices they make that affect their teaching. The types of learning activities educators choose as teachers are directly related to their experiences, which in turn affect the multiple intelligence profile of their students.

MI theory can contribute to language teaching in a number of ways. According to Botelho (2003), MI theory has helped teachers to reflect on their practice, and has given them a basis to develop and enhance their focus. It has also helped teachers to encourage themselves to look beyond the narrow confines of teaching plans and curriculum. To show the importance of multiple intelligence theory in language teaching, Richards and Rodgers (2001) argue that $\mathrm{MI}$ is richest in proposals for lesson organization and planning. Similarly, Viens (1999) holds that MI application provides a range of activities in the classroom to ensure learners the opportunity to develop and enhance abilities in a range of intelligence areas.

It should be noted, of course, that the application of MI theory in the classroom depends on learners' needs, interests, and preferences. (Christison, 1998). In addition, Green and Tanner (2005) admit that "making MI theory work in practice might seem challenging, yet it can be very 
satisfying for participants who find the learning more enjoyable, more personally relevant and more motivating" (p.320).

Another advantage of MI theory is that it seeks to cultivate the various ways in which learners reflect intelligently; so, its outcomes differ from predictable outcomes of traditional education. Eisner (2003) is of the opinion that "If one of the important aims of education is the cultivation of the students' unique capacities, then acknowledging differences in the ways in which children and adolescents are smart would, one might think, be of extraordinary importance" (p.32).

Nikolva (2007) maintains that in MI theory teachers may encounter lack of resources and overcrowded classrooms. Classifying and comparing learners' abilities in MI classroom may be difficult. On the other hand, MI application has many benefits for teachers and learners; "the theory broadens the vision of education. Teachers acknowledge that students learn in different ways and thus the different kinds of intelligence would allow different ways of teaching, rather than one. Students begin to understand how they are intelligent" (p.108).

MI theory may also have implications for reading comprehension and vocabulary learning. As to reading comprehension, Gaines and Lehmann (2002) showed that the use of MI theory improved learners' reading comprehension and enhanced their academic performance. In another study, Owolabi and Okebukola (2009) showed that reading comprehension in MI classrooms enhances learners' interaction with the print and ideas presented. Furthermore, according to Abdulkader, Gundogdu and Eissa (2009), the implementation of MI theory coupled with increased parental involvement can lead to substantial gains in the learners' reading comprehension and vocabulary knowledge.
In much the same vein, Motallebzadeh and Manuchehri (2008), focusing on the relationship between $\mathrm{MI}$ and reading comprehension of learners, hold that MI theory can improve learners' reading skill, especially by logical intelligence.

As to vocabulary learning, in MI classrooms, learners vocabulary knowledge can be enhanced by visual techniques, verbal explanation, and linguistic mnemonics. In visualization, learners can pair pictures with the words they need to learn. Verbal-explanation is the best method to show the meaning of abstract worlds. In MI classrooms, teachers use examples, situations, synonyms, antonyms and definitions.

A number of studies have investigated the effects of MI on various aspects of second and foreign language learning.

Christison (1996) studied the application of his own teaching style as it applies to MI theory. The findings of his study clarify how MI theory informs teaching and learning in his classroom, and he concludes that there is a relationship between the learning activities and his own MI profile.

Visser, Ashton, and Vernon (2006) conducted a study in which they applied two objective ability tests for each MI. The results of their study showed that only bodily-kinesthetic, intrapersonal and musical intelligences are not correlated with general intelligence. In another study, Tirri and Nokelainen (2008) worked on the latest version of the MI profiling questionnaire that was tested with Finnish preadolescents and adults. The major findings of the study were as follows: "(1) logical intelligence correlates positively with spatial intelligence; (2) linguistic intelligence correlates positively with intrapersonal intelligence; (3) linguistic and intrapersonal scales correlate positively 
with the spiritual and environmental intelligences" (p. 206).

MI theory can be used in the teaching of a chosen course. Xie and Lin (2009) conducted a study to explore the effects of MI teaching versus traditional teaching. It was found that the experimental group learners receiving MI instruction learned faster and better than the control group learners.

Gender differences in the assessment of MI have also been investigated. Kaur and Chhikara (2008) compared the mean scores of boys and girls. The results suggested that girls were stronger in linguistic and musical intelligences while boys were stronger in logical and bodily kinesthetic intelligences.

In another study, the relationship between gender differences and intelligence types was examined by Saricaoglu and Arikan (2009). They note that logical, musical, linguistic and intrapersonal intelligences are stronger in females. However, they conclude that there are no significant sex differences in MI types.

Campbell (1989) assessed MI in a group of third grade learners. His program aimed to teach seven intelligences to 27 learners and to engage MI in it. He concluded that his role as a teacher shifted as the learners worked at their multiple centers and he became a facilitator of learning in the classroom.

Akbari and Hosseini (2008) sought to determine the relationship between the use of language learning strategies and MI scores. Significant relationships were found between them. However, they reported no significant relationship between musical intelligence and any aspect of strategy use.

The use of MI theory in an online situation might seem challenging. Green and Tanner (2005) worked on the applications of MI theory in the online training of teachers. They hold that using MI theory as a framework in teaching and training can be very satisfying and enjoyable. They also argue that online training is a much more motivating type of instruction that accommodates learners MI. In other words, application of MI in an online situation can be useful regardless of the physical location of learners and teachers.

The discipline of distance education requires intellectual skills and abilities. In a study conducted by Ojo and Olakulein (2006), the importance of MI in the actualization of the objectives of distance learning was emphasized.

Veenema and Gardner investigated the significance of MI theory for improving effective educational materials and approaches. They argue that applications of MI could provide ways to improve knowledge of various minds.

It is possible to use MI as a learning intervention. Harding (2006) studied MI as a model for coaching and mentoring. The use of MI during coaching and mentoring process was found to improve learners' learning.

In their study, Hoffman and Frost (2006) studied the effects of emotional, cognitive and social intelligences on the interpersonal styles and methods. Findings showed that MI is a useful approach to predict interpersonal styles, and that MI framework focuses on assessment centers as a useful tool to enhance understanding of the important components of these styles and methods.

McKenzie (2009) focused on professional activities by using MI. He believed that it can be useful when a team of educators work together to create a situation in which each idea motivates more thinking and brain storming. He concluded that MI application in various 
activities develops new models for educators.

In a study conducted by Abdulkader et al. (2009), it was shown that MI-based program improves reading comprehension in disabled learners. Similarly, Motallebzadeh and Manouchehri (2008) studied the relationship between MI and reading comprehension of IELTS learners. Only logical intelligence was found to be related to learners' reading comprehension in IELTS.

Razmjoo (2008) investigated the relationship between MI and English language proficiency in Iran. He concluded that there is no significant relationship between MI and language proficiency in Iranian context.

To conclude, although there are a number of studies to explore the relationship between MI and language teaching and learning, there is still a gap in the relationship between MI on the one hand, and reading comprehension and vocabulary knowledge on the other. In order to fill this gap, this study aims to investigate the types of MI as predictors of reading comprehension and vocabulary knowledge.

\section{METHOD}

\section{Participants}

In the present study, a sample of $270 \mathrm{EFL}$ students (male and female) at Qazali and Parsian universities in Qazvin was selected. The initial number of participants was then reduced to 240 after the administration of the Michigan Test of English Language proficiency and McKenzie questionnaire and taking their results into account. 18 participants were excluded because their proficiency level did not match that of the other participants. Another 12 participants were removed because of not taking part in the McKenzie questionnaire. The participants were all adult learners of English ranging in age from 18 to 25 .

\section{Instruments}

To conduct the present study, four instruments were employed. They included: a Michigan test of English language proficiency (MTELP), a TOEFL vocabulary subtest, a TOEFL reading subtest, and an MI questionnaire. The MTELP was administered to check the homogeneity of the participants. MTELP is one of the popular tests for measuring the ESL or EFL learners' degree of language proficiency. It is a three-part, 100-item multiple-choice test containing 40 grammar items in a conversational format, 40 vocabulary items, and reading passages followed by 20 comprehension questions.

A multiple-choice TOEFL test was administered to the participants to measure their vocabulary and reading comprehension ability. It consisted of 60 questions including 30 vocabulary items and 30 reading comprehension items.

McKenzies (1999) questionnaire was used to assess the participants' intelligence profile. This questionnaire includes 90 statements related to each of the nine intelligences proposed by Gardner (1999). A validated sample of the test is available athttp://surfaquarium.com/MI/MIInvent. html.

\section{Procedures and Data analysis}

Initially, to homogenize the participants, a multiple-choice MTELP proficiency test was administered. It consisted of 100 grammar, vocabulary and reading comprehension questions. The mean and standard deviation of the scores were computed and those who scored more than one standard deviation away from (either above or below) the mean were excluded 
from the subsequent analyses. As a result, 18 of the participants had to be excluded from the study. 12 other participants were also excluded from the analyses because they failed to complete their cooperation and did not respond to the McKenzie questionnaire.

The vocabulary and reading comprehension subtests of a TOEFL test were used to measure the vocabulary knowledge and reading comprehension ability of the participants. Each subtest contained 30 items in multiple-choice format.

At the end, the McKenzie questionnaire was used to identify learners' intelligence profiles. Each learner was required to complete the questionnaire by placing either 0 or 1 next to each statement. 1 meant that it corresponded to the learner and 0 showed that it did not. Having administered the tests and the questionnaire and gathered the data, two separate multiple regression analyses were run to see which multiple intelligence types are better predictors of reading comprehension and vocabulary knowledge, respectively.

\section{FINDINGS AND DISCUSSION Investigation of the first research question}

The first question attempted to see which types of MI are predictors of reading comprehension. To this end, a multiple regression procedure was used. Table 1 summarizes the descriptive statistics for the reading scores as well as the various intelligences of the learners.

Table 1. Descriptive statistics for reading comprehension scores and multiple intelligences

$$
\text { Std. }
$$

\begin{tabular}{lccl} 
& Mean & Deviation & N \\
\hline Reading & 20.041 & 4.79260 & 240 \\
Natural & 32.750 & 19.78810 & 240 \\
Musical & 53.416 & 24.32334 & 240 \\
Existential & 30.750 & 16.01059 & 240 \\
Interpersonal & 52.458 & 25.25598 & 240 \\
Logical & 63.916 & 24.12644 & 240 \\
kinesthetic & 49.833 & 23.57161 & 240 \\
Verbal & 62.875 & 26.09255 & 240 \\
intrapersonal & 51.208 & 23.33579 & 240 \\
Visual & 55.375 & 25.77390 & 240 \\
\hline
\end{tabular}

Based on Table 1, logical intelligence group's mean score is the highest and existential intelligence group's mean score is the lowest. A correlation coefficient was run to see the degree of the relationship between reading and types of $\mathrm{MI}$, the results of which are shown in Table 2.

Table 2. Correlations among reading comprehension scores and multiple intelligences

\begin{tabular}{|c|c|c|c|c|c|c|c|c|c|c|}
\hline & $\begin{array}{l}\text { Readi } \\
\text { ng }\end{array}$ & $\begin{array}{l}\text { Natur } \\
\text { al }\end{array}$ & $\begin{array}{l}\text { Music } \\
\text { al }\end{array}$ & $\begin{array}{l}\text { Existent } \\
\text { ial }\end{array}$ & $\begin{array}{l}\text { Inter- } \\
\text { person } \\
\text { al }\end{array}$ & $\begin{array}{l}\text { Logic } \\
\text { al }\end{array}$ & $\begin{array}{l}\text { Kinesthet } \\
\text { ic }\end{array}$ & $\begin{array}{l}\text { Verba } \\
1\end{array}$ & $\begin{array}{l}\text { Intra- } \\
\text { person } \\
\text { al }\end{array}$ & Visual \\
\hline Reading & 1.000 & .365 & .568 & .434 & .524 & .377 & .512 & .423 & .441 & .483 \\
\hline Natural & & 1.000 & .312 & .431 & .321 & .289 & .347 & .331 & .343 & .364 \\
\hline Musical & & & 1.000 & .487 & .447 & .388 & .491 & .435 & .473 & .509 \\
\hline Existential & & & & 1.000 & .514 & .332 & .421 & .368 & .452 & .511 \\
\hline
\end{tabular}


Zarei \& Afshar, Multiple intelligences as predictors of reading comprehension ...

\begin{tabular}{|c|c|c|c|c|c|c|}
\hline Interpersonal & 1.000 & .289 & .411 & .347 & .411 & .496 \\
\hline Logical & & 1.000 & .270 & .645 & .382 & .419 \\
\hline Kinesthetic & & & 1.000 & .425 & .447 & .444 \\
\hline Verbal & & & & 1.000 & .444 & .398 \\
\hline Intrapersonal & & & & & 1.000 & .357 \\
\hline Visual & & & & & & 1.000 \\
\hline
\end{tabular}

As shown in Table 2, reading comprehension has the highest correlation with musical intelligence and the lowest correlation with natural intelligence. Table 3 shows how much variance is explained by all the nine predictors entered into the regression equation.

Table 3. Model Summary

\begin{tabular}{crccc}
\hline Model & $\mathrm{R}$ & $\begin{array}{c}\mathrm{R} \\
\text { Square }\end{array}$ & Adjusted R Square & $\begin{array}{l}\text { Std. Error of } \\
\text { the Estimate }\end{array}$ \\
\hline 1 & $.693^{\mathrm{a}}$ & .480 & .460 & 3.52326
\end{tabular}

a. Predictors: (Constant), visual, intrapersonal, natural, logical, kinesthetic, interpersonal, musical, existential, verbal

The result tells us that all intelligence types collectively account for $46 \%$ of the variance in reading comprehension. Table 4 , gives the results of the ANOVA performed on the model. The ANOVA tests the null hypothesis that the predictive power of the model is not significant. Based on Table 4, a significant result was shown.

Table 4. ANOVA on reading comprehension test

\begin{tabular}{llllcll}
\hline \multicolumn{2}{l}{ Model } & $\begin{array}{l}\text { Sum of } \\
\text { Squares }\end{array}$ & df & $\begin{array}{c}\text { Mean } \\
\text { Square }\end{array}$ & F & Sig. \\
\hline 1 & Regression & 2634.51 & 9 & 292.724 & 23.581 & $.000^{\text {a }}$ \\
& Residual & 2855.06 & 230 & 12.413 & & \\
& Total & 5489.58 & 239 & & & \\
\hline
\end{tabular}

a. Predictors: (Constant), visual, intrapersonal, natural, logical, kinesthetic, interpersonal, musical, existential, verbal

b. Dependent Variable: reading

To see how much of the variance in reading comprehension is accounted for by each of the nine predictors, the standardized coefficients and the significance of the observed t-value for each predictor were checked. The results are summarized in Table 5.

Table 5. Coefficients of multiple intelligences

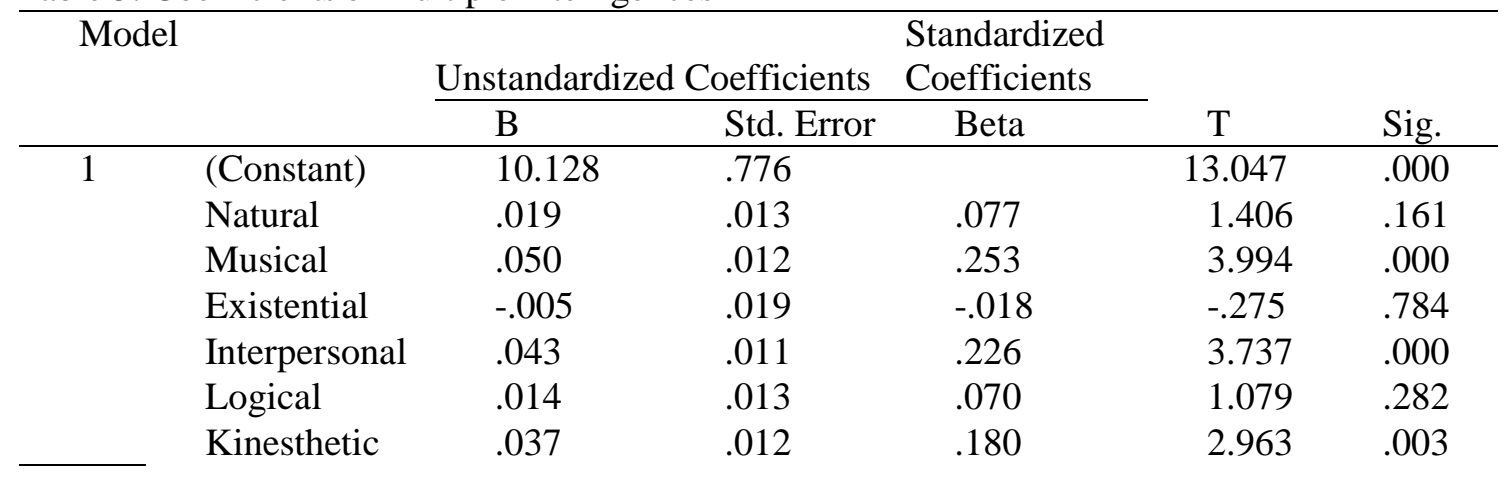




\begin{tabular}{llllll} 
Verbal & .007 & .012 & .036 & .538 & .591 \\
Intrapersonal & .012 & .012 & .058 & .971 & .332 \\
Visual & .015 & .012 & .079 & 1.237 & .218 \\
\hline
\end{tabular}

a. Dependent Variable: reading

As Table 5 shows, of all the nine predictors, musical, interpersonal, and kinesthetic intelligences account for a statistically significant portion of the variance in reading comprehension. Of these three intelligence types, musical intelligence is the best predictor of reading comprehension, accounting for approximately 25 percent of variance in reading comprehension. This means for every one standard deviation of change in one's musical intelligence, there will be about .25 of a standard deviation change in one's reading comprehension. This is closely followed by interpersonal intelligence, accounting for around $22 \%$ of the variance in reading comprehension. The kinesthetic intelligence is the least powerful predictor of the three, explaining only $18 \%$ of the variance in reading comprehension.
To analyze the data further, a stepwise multiple regression was conducted, which showed that musical, interpersonal, kinesthetic and logical intelligences entered into the regression equation (stepwise criteria: probability of $\mathrm{F}<=0.050$ ). Model summary (Table 6) shows that the musical intelligence and reading comprehension share $32 \%$ of variance. Musical and interpersonal intelligences together share $40 \%$ of variance with reading comprehension. The combinations of musical, interpersonal and kinesthetic intelligences explain $44 \%$ of variance in reading comprehension. In addition, logical intelligence makes an additional contribution of about one percent to the predictive power of the previous intelligence types in reading comprehension.

Table 6. Model Summary

\begin{tabular}{lllll}
\hline Model & & R Square & $\begin{array}{l}\text { Adjusted } \\
\text { Square }\end{array}$ & $\begin{array}{l}\text { Std. Error of } \\
\text { the Estimate }\end{array}$ \\
\hline 1 & $.568^{\mathrm{a}}$ & .323 & .320 & 3.95261 \\
2 & $.643^{\mathrm{b}}$ & .414 & .409 & 3.68400 \\
3 & $.673^{\mathrm{c}}$ & .454 & .447 & 3.56537 \\
4 & $.683^{\mathrm{d}}$ & .467 & .458 & 3.52872 \\
\hline
\end{tabular}

a. Predictors: (Constant), musical

b. Predictors: (Constant), musical, interpersonal

c. Predictors: (Constant), musical, interpersonal, kinesthetic

d. Predictors: (Constant), musical, interpersonal, kinesthetic, logical

e. Dependent Variable: reading

This means that musical, interpersonal, kinesthetic and logical intelligences were found to be positive predictors of reading comprehension. Table 7 , shows the Beta value and significance level of the observed t-value for each of the four intelligences that entered the regression equation.

Table 7. Coefficients of Multiple Intelligences

\begin{tabular}{ccccccc}
\hline Model & \multicolumn{5}{c}{ Standardized } \\
& & \multicolumn{2}{c}{ Unstandardized Coefficients } & Coefficients \\
& & B & Std. Error & Beta & T & Sig. \\
\hline 1 & (Constant) & 14.063 & .617 & & 22.802 & .000 \\
& Musical & .112 & .011 & .568 & 10.648 & .000
\end{tabular}




\begin{tabular}{ccccccc}
2 & (Constant) & 12.288 & .645 & & 19.060 & .000 \\
& Musical & .082 & .011 & .417 & 7.505 & .000 \\
& Interpersonal & .064 & .011 & .338 & 6.080 & .000 \\
& (Constant) & 11.417 & .659 & & 17.333 & .000 \\
Musical & .064 & .011 & .327 & 5.624 & .000 \\
& Interpersonal & .053 & .011 & .282 & 5.075 & .000 \\
& Kinesthetic & .048 & .012 & .235 & 4.127 & .000 \\
& (Constant) & 10.451 & .763 & & 13.693 & .000 \\
& Musical & .057 & .012 & .289 & 4.856 & .000 \\
& Interpersonal & .050 & .010 & .265 & 4.797 & .000 \\
& Kinesthetic & .046 & .011 & .226 & 3.998 & .000 \\
& Logical & .025 & .010 & .127 & 2.435 & .016 \\
\hline & & & & &
\end{tabular}

a. Dependent Variable: reading

Investigation of the second research knowledge. To this end, a standard multiple question regression and a stepwise regression analyses

The second question attempted to see which types of MI are predictors of vocabulary were run. Table 8 summarizes the descriptive statistics.

Table 8. Descriptive Statistics for vocabulary scores

\begin{tabular}{lccl}
\hline & Mean & Std. Deviation & N \\
\hline Vocabulary & 17.595 & 4.99615 & 240 \\
Natural & 32.750 & 19.78810 & 240 \\
Musical & 53.416 & 24.32334 & 240 \\
Existential & 30.750 & 16.01059 & 240 \\
Interpersonal & 52.458 & 25.25598 & 240 \\
Logical & 63.916 & 24.12644 & 240 \\
Kinesthetic & 49.833 & 23.57161 & 240 \\
Verbal & 62.875 & 26.09255 & 240 \\
Intrapersonal & 51.208 & 23.33579 & 240 \\
Visual & 55.375 & 25.77390 & 240 \\
\hline
\end{tabular}

It can be seen that the mean score of the logical intelligence group is the highest and the mean score of the existential intelligence group is the lowest. A correlation analysis was used to see the degree of the relationship among vocabulary test and types of MI, the results of which are shown in Table 9.

Table 9. Correlations among vocabulary scores and multiple intelligences

\begin{tabular}{lllllllllll}
\hline & $\begin{array}{l}\text { Voca } \\
\mathrm{b}\end{array}$ & $\begin{array}{l}\text { Nat } \\
\text { ural }\end{array}$ & $\begin{array}{l}\text { Musi } \\
\text { cal }\end{array}$ & $\begin{array}{l}\text { Existen } \\
\text { tial }\end{array}$ & $\begin{array}{l}\text { Interpers } \\
\text { onal }\end{array}$ & $\begin{array}{l}\text { Logi } \\
\text { cal }\end{array}$ & $\begin{array}{l}\text { Kinesth } \\
\text { etic }\end{array}$ & $\begin{array}{l}\text { Ver } \\
\text { bal }\end{array}$ & $\begin{array}{l}\text { Intraper } \\
\text { sonal }\end{array}$ & $\begin{array}{l}\text { Visu } \\
\text { al }\end{array}$ \\
\hline Vocabulary & 1.000 & .395 & .587 & .424 & .465 & .447 & .499 & .526 & .469 & .537 \\
Natural & & 1.00 & .312 & .431 & .321 & .289 & .347 & .331 & .343 & .364 \\
Musical & & & 1.00 & .487 & .447 & .388 & .491 & .435 & .473 & .509 \\
Existential & & & & 1.00 & .514 & .332 & .421 & .368 & .452 & .511 \\
Interpersonal & & & & & 1.00 & .289 & .411 & .347 & .411 & .496 \\
Logical & & & & & & 1.00 & .270 & .645 & .382 & .419 \\
Kinesthetic & & & & & & & 1.000 & .425 & .447 & .444 \\
Verbal & & & & & & & & 1.00 & .444 & .398
\end{tabular}


As it is shown, vocabulary knowledge has the highest correlation with musical intelligence and the lowest correlation with natural intelligence. The model summary tells us that the combination of all intelligence types account for around $50 \%$ of the total variance in vocabulary test.

Table 10. Model Summary ${ }^{\mathrm{b}}$

\begin{tabular}{crcccc}
\hline Model & $\mathrm{R}$ & R Square & $\begin{array}{l}\text { Adjusted } \\
\text { Square }\end{array}$ & $\mathrm{R}$ & $\begin{array}{l}\text { Std. Error of } \\
\text { the Estimate }\end{array}$ \\
\hline 1 & $.722^{\mathrm{a}}$ & .521 & .502 & 3.525
\end{tabular}

a. Predictors: (Constant), visual, intrapersonal, natural, logical, kinesthetic, interpersonal, musical, existential, verbal

b. Dependent Variable: vocabulary

Table 11 gives the results of the ANOVA performed on the model, testing the null hypothesis that the predictive power of the model is insignificant.

Table 11. ANOVA on vocabulary test

\begin{tabular}{|c|c|c|c|c|c|c|}
\hline \multicolumn{2}{|c|}{ Model } & $\begin{array}{l}\text { Sum of } \\
\text { Squares }\end{array}$ & $\mathrm{df}$ & Mean Square & $\mathrm{F}$ & Sig. \\
\hline 1 & Regression & 3107.352 & 9 & 345.261 & 27.781 & $.000^{\mathrm{a}}$ \\
\hline & Residual & 2858.444 & 230 & 12.428 & & \\
\hline & Total & 5965.796 & 239 & & & \\
\hline
\end{tabular}

a. Predictors: (Constant), visual, intrapersonal, natural, logical, kinesthetic, interpersonal, musical, existential, verbal

b. Dependent Variable: vocabulary

Based on Table 11, a significant result was shown. To see how much of the variance in vocabulary knowledge is accounted for by each of the nine predictors, the standardized coefficients and the significance of the observed t-value for each predictor were checked. The results are summarized in Table 12.

Table 12. Coefficient of Multiple Intelligences

\begin{tabular}{|c|c|c|c|c|c|c|}
\hline \multirow{3}{*}{\multicolumn{2}{|c|}{ Model }} & & & \multirow{2}{*}{$\begin{array}{l}\text { Standardized } \\
\text { Coefficients }\end{array}$} & \multirow[b]{3}{*}{$\mathrm{t}$} & \multirow[b]{3}{*}{ Sig. } \\
\hline & & \multicolumn{2}{|c|}{ Unstandardized Coefficients } & & & \\
\hline & & $\mathrm{B}$ & Std. Error & Beta & & \\
\hline \multirow[t]{10}{*}{1} & (Constant) & 6.560 & .777 & & 8.446 & .000 \\
\hline & Natural & .025 & .013 & .099 & 1.876 & .062 \\
\hline & Musical & .052 & .012 & .254 & 4.178 & .000 \\
\hline & Existential & -.017 & .019 & -.054 & -.876 & .382 \\
\hline & Interpersonal & .020 & .011 & .102 & 1.754 & .081 \\
\hline & Logical & .013 & .013 & .062 & .997 & .320 \\
\hline & Kinesthetic & .025 & .012 & .117 & 2.019 & .045 \\
\hline & Verbal & .033 & .012 & .171 & 2.638 & .009 \\
\hline & Intrapersonal & .018 & .012 & .083 & 1.438 & .152 \\
\hline & Visual & .033 & .012 & .172 & 2.827 & .005 \\
\hline
\end{tabular}




\begin{tabular}{|c|c|c|c|c|c|c|}
\hline \multirow[t]{2}{*}{$\mathrm{Mo}$} & & & & \multicolumn{3}{|l|}{ Standardized } \\
\hline & & $\mathrm{B}$ & Std Error & $\frac{\text { Coefficients }}{\text { Beta }}$ & $\mathrm{t}$ & Sig. \\
\hline \multirow[t]{10}{*}{1} & (Constant) & 6.560 & .777 & & 8.446 & .000 \\
\hline & Natural & .025 & .013 & .099 & 1.876 & .062 \\
\hline & Musical & .052 & .012 & .254 & 4.178 & .000 \\
\hline & Existential & -.017 & .019 & -.054 & -.876 & .382 \\
\hline & Interpersonal & .020 & .011 & .102 & 1.754 & .081 \\
\hline & Logical & .013 & .013 & .062 & .997 & .320 \\
\hline & Kinesthetic & .025 & .012 & .117 & 2.019 & .045 \\
\hline & Verbal & .033 & .012 & .171 & 2.638 & .009 \\
\hline & Intrapersonal & .018 & .012 & .083 & 1.438 & .152 \\
\hline & Visual & .033 & .012 & .172 & 2.827 & .005 \\
\hline
\end{tabular}

a. Dependent Variable: vocabulary

Based on Table 12, of all the nine predictors, only musical, verbal, visual, and kinesthetic intelligences account for a statistically significant portion of the variance in the dependent variable (Vocabulary Knowledge). Of these four intelligence types, musical intelligence is the best predictor of vocabulary knowledge, accounting for approximately 25 percent of variance in vocabulary knowledge. This means for every one standard deviation of change in one's musical intelligence, there will be about .25 of a standard deviation change in one's vocabulary knowledge. This is closely followed by verbal and visual intelligences; accounting for around $17 \%$ of the variance in vocabulary knowledge. Kinesthetic intelligence is the least powerful predictor of the four, explaining only $11 \%$ of the variance in vocabulary knowledge.

To analyze the data further, a stepwise multiple regression was conducted, which showed that musical, interpersonal, kinesthetic, logical, and natural intelligences entered the regression equation (stepwise criteria: probability of $\mathrm{F}<=0.050$ ).

Table 13. Model Summary

\begin{tabular}{lllll}
\hline Model & R & R Square & $\begin{array}{l}\text { Adjusted } \\
\text { Square }\end{array}$ & $\begin{array}{l}\text { Std. Error of } \\
\text { the Estimate }\end{array}$ \\
\hline 1 & $.587^{\mathrm{a}}$ & .345 & .342 & 4.05173 \\
2 & $.660^{\mathrm{b}}$ & .435 & .430 & 3.77065 \\
3 & $.693^{\mathrm{c}}$ & .481 & .474 & 3.62285 \\
4 & $.705^{\mathrm{d}}$ & .496 & .488 & 3.57563 \\
\hline
\end{tabular}

a. Predictors: (Constant), musical

b. Predictors: (Constant), musical, verbal

c. Predictors: (Constant), musical, verbal, visual

d. Predictors: (Constant), musical, verbal, visual, kinesthetic

e. Predictors: (Constant), musical, verbal, visual, kinesthetic, natural

f. Dependent Variable: vocabulary

Table 13 shows that musical intelligence and vocabulary knowledge share $34 \%$ of variance. Musical and verbal intelligences together share $43 \%$ of variance with vocabulary knowledge. The combination of musical, verbal, visual, and kinesthetic intelligences explain $48 \%$ of variance in vocabulary test. In addition, natural intelligence makes an additional contribution of about one percent to the predictive power of the previous intelligence types in vocabulary knowledge. To see how much of the variance 
in vocabulary knowledge is accounted for by each of the nine predictors, the standardized coefficients and the significance of the observed t-value for each predictor were checked. The results are summarized in Table 14.

Table 14. Coefficients ${ }^{\mathrm{a}}$ of Multiple Intelligences

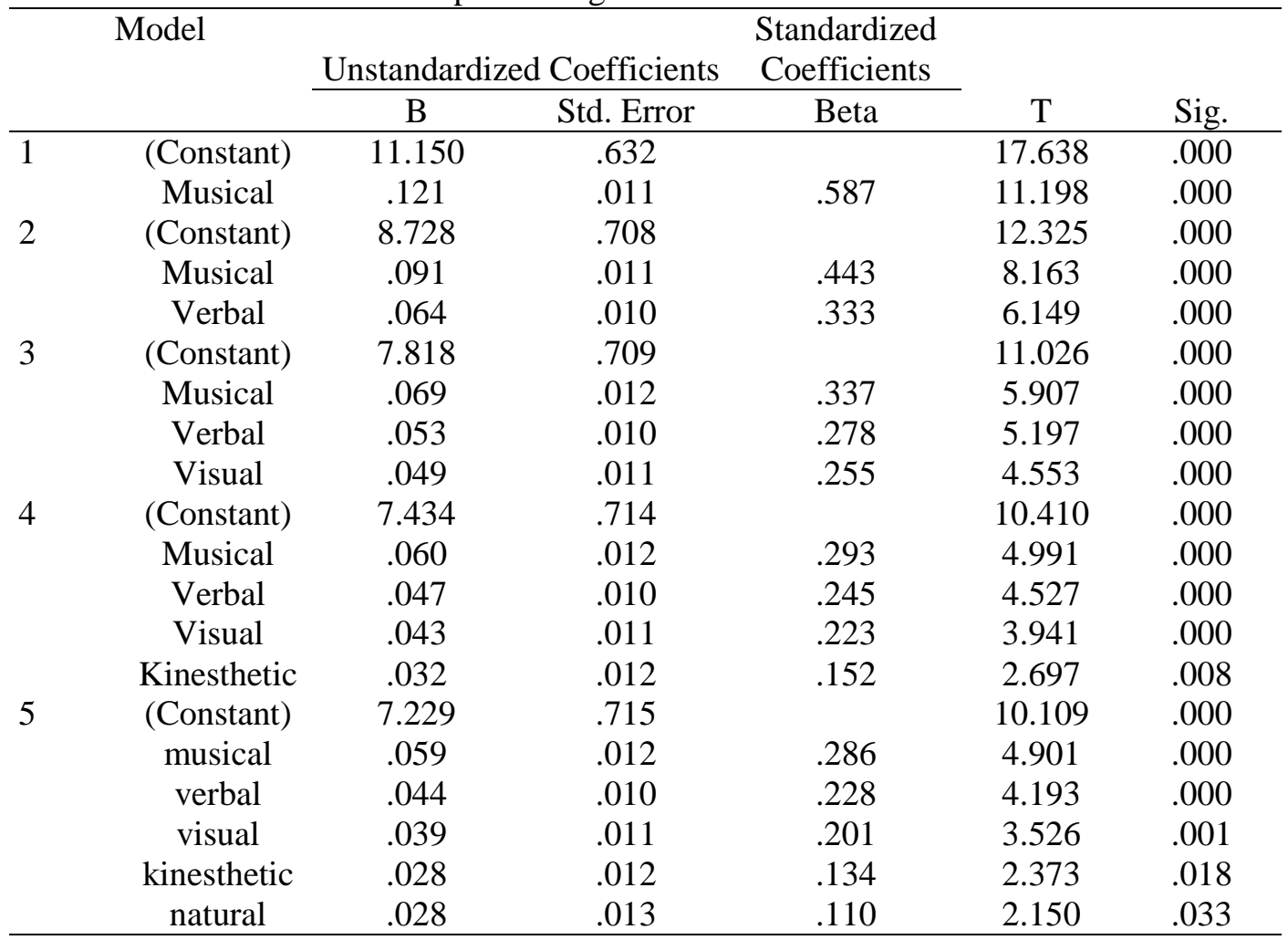

a. Dependent Variable: vocabulary

As Table 14 shows, of the nine predictors, only musical, verbal, visual, kinesthetic, and natural intelligences account for a statistically significant portion of the variance in vocabulary knowledge. Of these five intelligence types, musical intelligence is the best predictor, accounting for approximately 28 percent of variance in vocabulary knowledge. This is closely followed by verbal intelligence, accounting for around $22 \%$, and visual intelligence accounting for around $20 \%$ of the variance in vocabulary knowledge. Kinesthetic and natural intelligences are the least powerful predictors of the five, explaining $13 \%$ and $11 \%$ of the variance in vocabulary knowledge, respectively.

The present study attempted to investigate types of MI as predictors of reading comprehension and vocabulary knowledge. Some of the findings of the present study are in accordance with a number of previous studies (e.g. Akbari \& Hosseini, 2008; Alghazo, Obeidat, Al-trawneh, \& Alshraideh 2009; Arnold \& Fonseca 2004; Hashemi 2007) which support the present findings in that they all, much like the present study, emphasized different types of MI as predictors of reading comprehension and vocabulary knowledge. However, the findings are different from some other studies (e.g. Razmjoo, 2008; Saricaoglu \& Arikan, 2009), which did not find MI types as predictors of reading comprehension and vocabulary knowledge.

According to Hashemi (2007), kinesthetic and verbal intelligences make significant contribution to predicting reading comprehension. So, the present study is partially in line with Hashemi's study in that kinesthetic intelligence turned out to be a predictor of reading comprehension. However, 
unlike Hashemi's study, verbal intelligence was not found to be a predictor of reading comprehension here. Moreover, Akbari and Hosseini (2008) showed verbal intelligence as the most appropriate predictor of language proficiency. This is partially supported by the findings of the present study, as the participants' verbal intelligence turned out as the second best predictor of vocabulary scores. The present study is also compatible with that of Medina (1993), which diagnosed musical intelligence as a significant predictor of language ability. In this study, musical intelligence was the strongest predictor of both vocabulary and reading comprehension ability.

On the other hand, the results of the present study are different from a number of studies reviewed earlier. This study revealed that some MI types could be predictors of reading comprehension and vocabulary knowledge, but Razmjoo (2008) found no significant relationship between MI and English language proficiency in Iranian context. Motallebzadeh and Manuchehri (2008) also reported that only logical intelligence has a significant relationship with reading comprehension and the eight other types have no significant relationship with reading comprehension.

One of the possible reasons for such differences may be partially attributable to the gender differences leading to different abilities of the participants. In this study, gender was not taken into account. However, studies such as Kaur and Chhikara (2008), Razmjoo (2008), Saricaoglu and Arikan (2009), and Shearer (2006) emphasize the prominent role of gender differences in MI-based programs.

Another possible reason could be differences in the proficiency level of the participants. In this study, the participants were intermediate level students while in studies such as Razmjoo (2008), the participants were $\mathrm{Ph} . \mathrm{D}$ students and in Kaur and Chhikara (2008), the participants were young adolescents.

One of the surprising findings of this study was that linguistic intelligence was not a significant predictor of either vocabulary or reading comprehension. Since both of the above are components of language, it is hard to explain why this happened. Another surprise was that logical/mathematical intelligence was not among the predictors of vocabulary and reading comprehension ability. Since both language and mathematics learning involve analytic processing, one would expect both vocabulary and reading ability to be closely correlated with mathematical intelligence.

The above mentioned areas of conflict are probably indicative of the need for further research. Perhaps what makes this study different from other studies is that it was carried out in an EFL context while most of the mentioned studies were conducted in ESL settings.

\section{CONCLUSION}

Based on the findings of the present study, a number of points may be concluded. First, the findings indicate that musical intelligence is the best predictor of both vocabulary and reading comprehension. Since musical intelligence involves the ability to sing, and to understand and use rhythm, it can be concluded that the inclusion of poems and songs should facilitate both reading comprehension and vocabulary learning. Second, since visual intelligence turned out to be significantly correlated with vocabulary knowledge, the conclusion to be drawn is that pictorial presentation of vocabulary, or combining vocabulary with pictures in the form of pictorial glosses or photo dictionaries, may positively influence vocabulary learning. In addition, since reading and vocabulary knowledge are significantly correlated with only three and four of the intelligences, respectively, activities could be incorporated in the classroom to activate only the right kind of intelligence to improve the learning conditions. In short, the findings of the present study can help teachers to obtain a clear understanding of MI theory and its applicability in a pedagogical context. Teachers can find new ways of teaching to consider their learners' need as well as their intelligence profiles.

The present study may also have implications for material developers and syllabus designers. They should develop materials and course books to improve the 
specifications of MI types as predictors of language learning.

\section{REFERENCES}

Abdulkader, F., Gundogdu, K., \& Eissa, M. (2009). The effectiveness of Multiple Intelligences-based program on improving certain reading skills in 5th-year primary learning disabled students. Electronic Journal of Research in Educational Psychology, 7(3), pp. 673690.

Akbari, R., \& Hosseini, K. (2008). Multiple intelligences and language learning strategies: Investigating possible relations. System, 36(2), pp. 141-155.

Alghazo, K., Obeidat, H., Al- trawneh, M., \& Alshraideh, M. (2009). Types of multiple intelligences in social studies, Arabic and English language textbooks for the first three grades. European Journal of Social Sciences, 12(1), pp. 7-20.

Armstrong, T. (1994). Multiple intelligences: seven ways to approach curriculum. Educational Leadership.

Armstrong, T. (1995). Multiple intelligences in the classroom. Alexandria, VA: ASCD.

Arnold, J., \& Fonseca, M.C. (2004). Multiple intelligence theory and foreign language learning: A Brain-based perspective. IJES, 4(1), pp. 119-136.

Botelho, M. (2003). Multiple Intelligences theory in English language teaching: An analysis of current textbooks, materials and teachers' perceptions. Master thesis. Ohio University.

Campbell, B. (1989). Multiplying intelligence in the classroom. Learning's On The Beam, 4(2), pp. 7167.

Christison, M. A. (1996). Teaching and learning languages through multiple intelligences. TESOL, 6(1), pp. 10-14.

Christison, M. A. (1998). Applying multiple intelligences theory in pre-service and inservice TEFL education programs. English Teaching Forum, 36(2), pp. 2-13.
Christison, M. A. (1999). Multiple intelligences. ESL Magazine, 2(5), pp. 1013.

Eisner, E. (2004). Multiple intelligences: Its tensions and possibilities. Teachers College Record, 106(1), pp. 31-39.

Gaines, D., \& Lehmann, D. (2002). Improving student performance in reading comprehension through the use of Multiple Intelligences. MA thesis, Saint Xavier University and Skylight Professional Development Field-based Master's Program. ED 467515.

Gardner, H. (1983). Frames of mind. New York: Basic Books.

Gardner, H. (1993). Multiple intelligences: The theory in practice. New York: Basic books.

Gardner, H. (1999). Intelligence reframed. New York: Basic Books.

Green, C., \& Tanner, R. (2005). Multiple intelligences and online Teacher education. ELT Journal, 59(4), pp. 312321.

Harding, C. (2006). Using the multiple intelligences as a learning intervention: A model for coaching and mentoring. International Journal of Evidence Based Coaching and Mentoring, 4(2), 19-39.

Hashemi, A. (2007). On the relationship between multiple intelligences and reading comprehension tasks: An authentic MI Theory-based assessment. Unpublished doctoral Dissertation, University of Roudehen, Iran.

Hoffman, B. J., \& Frost, B. C. (2006). Multiple intelligences of transformational leaders: an empirical examination. International Journal of Manpower, 27(1), pp. 37-51.

Kaur, G., \& Chhikara, S. (2008). Assessment of Multiple Intelligence among Young Adolescents. Hum. Ecol., 23(1), 7-11.

McKenzie, W. (2002). Multiple intelligences and instructional technology. Eugene, OR: ISTE Publications.

McKenzie, W. (2009). Walking the walk: Multiple intelligences in educator professional development. Massachusetts Computer Using Educators, pp. 11-29. 
McKenzie, W. (1999). Multiple

Intelligences Survey. http://surfaquarium.com/MI/MIinvent. htm

Medina, S. (1993). The Effect of music on second language vocabulary acquisition. National Network for Early Language learning, 6(3), pp. 1-8.

Motallebzadeh, K., \& Manouchehri, M. (2008). On the Relationship between Multiple Intelligences and Reading Comprehension gain on IELTS. SID Journal, 42(2), pp. $135-140$.

Nikolva, K. (2007). Multiple intelligences theory and educational practice, Anпиal Assen Zlatarov, 36(2), pp. 105-109.

Ojo, O. D., \& Olakulein, F. K. (2006). The place of multiple intelligence in achieving the objectives and goals of open and distance learning institutions: A critical analysis. Turkish Online Journal of Distance Education-TOJDE, 7(3), pp. 1927.

Owolabi, T., \& Okebukola, F. (2009). Improving the reading ability of science students through study groups and multiple intelligences. US-China Education Review, 6(2). pp. 38-43.

Razmjoo, S. A. (2008). On the relationship between multiple intelligences and language success. The Reading Matrix, $8(2)$, pp. 155-174.
Richards, J., \& Rodgers, T. (2001). Approaches and methods in language teaching. Second edition. Cambridge: Cambridge University Press.

Saricaoglu, A., \& Arikan, A. (2009). A study of multiple intelligence, foreign language success and some selected variables. Journal of Theory and Practice in Education 5(2), pp. 110-122

Shearer, C. B. (2006). Reading skill and multiple intelligences. Researched and consulting: Kent, Ohio.

Tirri, K., \& Nokelainen, P. (2008). Identification of multiple intelligences with the Multiple Intelligence Profiling Questionnaire III. Psychology Science Quarterly, 50(2), 206-$-221$.

Veenema, S. \& Gardner, H. (1996). Multimedia and multiple intelligences. The American Prospect, 29, pp. 69-75.

Viens, J. (1999). Understanding multiple intelligences: The theory behind the practice. NCSALL, 3(1), pp. 6-10.

Visser, B., Ashton, M., \& Vernon, P. (2006). Beyond g: Putting multiple intelligences theory to the test. Intelligence, 34(5), pp. 487-502.

Xie, J. C., \& Lin, R. L. (2009). Research on multiple intelligences teaching and assessment. Asian Journal of Management and Humanity Sciences, 4(2), pp. 106-124. 